Acta vet. scand. $1986,27,299-301$.

Brief Communication

\title{
ISOLATION OF A HERPESVIRUS SEROLOGICALLY RELATED TO BOVINE HERPESVIRUS 1 FROM A REINDEER (RANGIFER TARANDUS)
}

Serological evidence of exposure of reindeer (Rangifer tarandus) to a virus related to bovine herpesvirus 1 (BHV1) (Synonym: Infectious bovine rhinotracheitis (IBR) virus) has been reported in Canada (El Azhary 1979) and the USA (Dieterich 1981). A serological survey conducted in Finnish Lapland also detected neutralising antibodies to BHV1 in reindeer sera; $23 \%$ of 300 reindeer had detectable antibodies, whereas none of 300 cattle sera from the same region contained antibodies to BHV1 (Ek-Kommonen et al. 1982). There is currently no evidence of BHV1 infection of cattle in Finland, so the isolation and characterisation of the reindeer herpesvirus was of considerable interest. This short communication describes the isolation and preliminary characterisation of a herpesvirus from a reindeer following the administration of dexamethasone.

Specimens for virus isolation were collected at the experimental farm of the Finnish reindeer breeders' association in Northern Lapland, in an experiment which lasted 7 days. Two young females, with neutralising antibody to BHV1, were injected intramuscularly on 4 consecutive days (designated $0-3$ ) with dexamethasone (Dexa-Korti ${ }^{\circledR}$, Laake Oy) at a dose rate of $0.1 \mathrm{mg} / \mathrm{kg} /$ day. Specimens for virus isolation were collected daily (days 1 to 6 ) from the nose and vagina of each animal. After collection, each cotton wool swab was placed in $1 \mathrm{ml}$ of Hank's BSS containing 200 iu penicillin, and $0.4 \mathrm{mg}$ streptomycin, and transported in liquid nitrogen to the laboratory where they were stored at $-70^{\circ}$ until examined.

Supernatants of centrifuged specimen were tested for the presence of cytopathic viruses during 2 weekly passages in secondary reindeer kidney cells. Neither animal showed any evidence of disease but specimens collected from the vagina of 1 animal on days 5 and 6 induced an obvious cytopathic effect (CPE) during the first passage. All other cultures remained 
negative. The CPE was typical of that induced by herpesviruses with rounding-up of cells and syncytium formation. The infectivity of virus stocks, prepared in reindeer kidney cells and later in a semi-continuous line of embryonic bovine trachea cells, was ether labile, heat stable $\left(50^{\circ} \mathrm{C}\right.$ for $\left.30 \mathrm{~min}\right)$, retained by $100 \mathrm{~nm}$ filters but passed through $220 \mathrm{~nm}$ pore diameter filters and the agent was further identified as a herpesvirus by electron microscopy. Infected tissue culture cells grown on Lab-tek chamber slides (Miles Scientific Ltd.) showed a specific intracytoplasmic fluorescence when stained in an indirect fluorescence test using rabbit antiserum against BHV1 (Colorado strain) as the first stage serum. Further evidence that the reindeer virus was antigenically related to BVH1 was derived from a plaque reduction assay using plaque purified virus and cattle convalescent and rabbit hyperimmune sera against a Scottish field isolate of BHV1 (strain 6660). The $\log _{10}$ plaque reduction neutralisation indices for the 2 sera were respectively 1.1 and 2.1 against the reindeer virus compared with the equivalent figures of 3.6 and 6.0 against BVH1 (strain 6660), suggesting that the reindeer virus was different from BVH1. Further studies on the relationships between the reindeer herpesvirus, BHV1 and a virus isolated from red deer (Cervus elaphus) (Inglis et al. 1983) are in progress and will be reported in due course.

Many wild ungulates have serological evidence of exposure to BHV1 or a serologically related virus (Plowright 1981). There is preliminary evidence that such viruses from buffalo and red deer are distinguishable, particularly by genome analysis using restriction endonucleases and that they do not readily infect cattle (Brake \& Studdert 1985, Reid et al. 1986). Further work with the reindeer herpesvirus, whose isolation is reported here, will contribute to a greater understanding of the epidemiology and pathogenicity of ruminant alphaherpesviruses.

\section{ACKNOWLEDGEMENT}

We thank Dr. Erkki Neuvonen for helping to initiate our collaboration on this work.

C. Ek-Kommonen \& S. Pelkonen,

the National Veterinary Institute, Helsinki, Finland, and

$P$. F. Nettleton,

the Moredun Research Institute, Edinburgh, Scotland, 


\section{REFERENCES}

Brake, F. \& M. J. Studdert: Molecular epidemiology and pathogenesis of ruminant herpesviruses including bovine, buffalo and caprine herpesviruses 1 and bovine encephalitis herpesvirus. Aust. vet. J. 1985, 62, 331-334.

Dieterich, R.: In: Alaskan Wildlife Disease. Ed. R. A. Dieterich, University of Alaska, Fairbanks, Alaska, USA 1981, p. 28.

Ek-Kommonen, C., P. Veijalainen, M. Rantala \& E. Neuvonen: Neutralizing antibodies to bovine herpes virus 1 in reindeer. Acta vet. scand. $1982,23,565-569$.

El Azhary, S.: Serological evidence of IBR and BVD infection in caribou (Rangifer tarandus). Vet. Rec. 1979, 105, 336.

Inglis, D. M., J. M. Bowie, M. J. Allan \& P. F. Nettleton: Ocular disease in red deer calves associated with a herpesvirus infection. Vet. Rec. 1983, 113, 182-183.

Plowright, W.: In: Infectious Diseases of Wild Mammals. 2dn Edition. Ed. J. W. Davis, L. H. Karstad \& D. O. Trainer, Iowa State University Press, Ames, Iowa, USA 1981, p. 138.

Reid, H. W., P. F. Nettleton, I. Pow \& J. A. Sinclair: Experimental infection of red deer (Cervus elaphus) and cattle with a herpesvirus isolated from red deer. Vet. Rec. 1986, 118, 156.

(Received August 15, 1986).

Reprints may be requested from: C. Ek-Kommonen, the National Veterinary Institute, Hämeentie 57, 00550 Helsinki 55, Finland. 